\title{
Seasonal Incidence of Thrips, Scirtothrips dorsalis Hood on Grapes, Vitis vinifera L. (cv. Thompson Seedless) in Bijapur
}

\author{
Nagaraj R. Patil ${ }^{1}$, A.M. Nadaf ${ }^{1}$, Gangadhar B. Narabenchi ${ }^{1}$, D.R. Patil ${ }^{2}$ and B.S. Sagar ${ }^{2}$ \\ ${ }^{1}$ Department of Horticultural Entomology, College of Horticulture, University of Horticultural \\ Sciences, Bagalkot - 587 104, Karnataka, India \\ ${ }^{2}$ Department of Fruit Science, College of Horticulture, University of Horticultural Sciences, \\ Bagalkot - 587 104, Karnataka, India \\ *Corresponding author
}

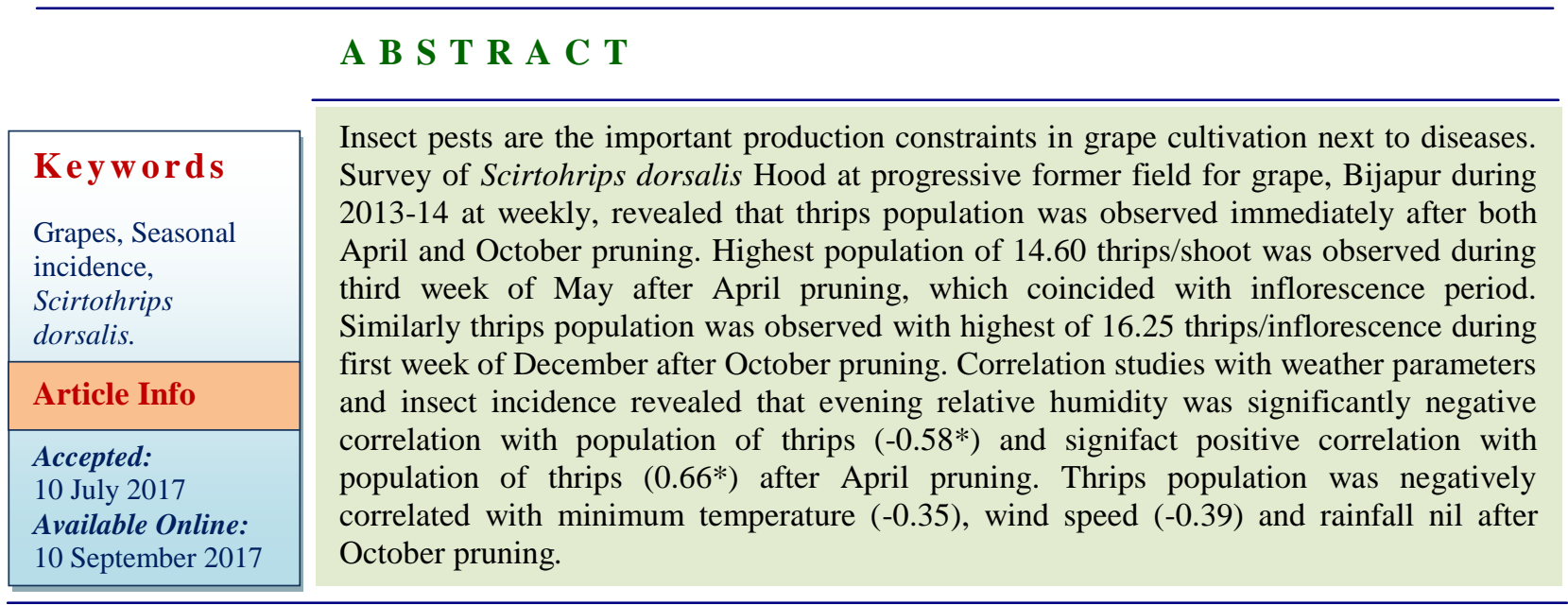

\section{Introduction}

In recent years, two species of phytophagus thrips belonging to the family Thripidae i.e. Scirtothrips dorsalis and Thrips sps have been found causing serious damage to fruits crop specially Grape, is most common fruits. Bijapur is one of the major districts of Karnataka in grape cultivation (6137 ha) with an annual production of 1.22 lakh tones (Anon., 2012). The fresh grape berries are good source of sugars, carbohydrates, vitamins, proteins and minerals. Fruits are used for table purpose, wine, juice, raisins and canning. Fresh and dried fruits have various uses in Ayurvedic and Unani medicine.
The fruits are considered to be laxative, stomachic, diuretic and cooling agents. The juice of unripe berries is used as astringent in throat infections. Tannins can also be extracted as a byproduct from wine industry. It is an important fruit crop, earning foreign exchange (Dry et al., 2004).

The infestation by thrips species like $R$. cruentatus in grape take whitish hue, acquire a withered appearance and then turn brown. Leaves ultimately curl up and drop off. Such vines either do not bear fruits or fruits drop off prematurely, even matured fruits are of 
poor quality. Wherein, the thrips like $S$. dorsalis lacerate and suck the sap from the berries of all stages leading to the formation of black corky surface resulting in scab formation (Reddy, 1957). This results in the hampering of marketability and export.

Among various factors responsible for low production, thrips are one of the major constraints and cause greater loss to the crops (Verma et al., 2012). The information on incidence and population dynamics of thrips infesting grape in Bijapur district is investigated and results thus, obtained are reported herein.

\section{Materials and Methods}

The present study was undertaken during 2013-14 season in progressive former field at Khedagi (Bijapur district) and Research plot of UHS Bagalkot. Ten unprotected vines were used for this study. The observations on thrips numbers were recorded as mentioned earlier at weekly interval. Simultaneously, weather parameters viz., maximum temperature, minimum temperature, relative humidity, total rainfall and wind speed were collected from RARS Bijapur weather station. These were averaged for a week (except for rainfall, which was summed up for a week) and the mean number of thrips was correlated with the meteorological data. For the correlation studies, weekly mean values of weather parameters viz., maximum and minimum temperature in degree Celsius, relative humidity in percentage, wind speed in $\mathrm{km} / \mathrm{hr}$ and total rainfall in $\mathrm{mm}$ were considered.

\section{Results and Discussion}

\section{April pruning}

The population of thrips after April pruning was recorded from last week of April (18 Standard week) to first week of August (32
Standard week), 2013 (Table 1). The mean population of thrips at different stages of vine in Bijapur district ranged from 0.21 to 14.60 thrips/bud/shoot. Less numbers of thrips were recorded after April pruning at the bud stage (0.21 thrips/bud). However, the number reached peak on third week of May (14.60 thrips/shoot). The present investigation is in close agreement with the findings of Kirk (1985) that higher temperature encourages physiological development of thrips, thus increasing the rate of population growth. The mean population of thrips decreased after third week of May 2013 (21 $1^{\text {th }}$ Standard week).

\section{October pruning}

The population of thrips after October pruning was recorded from last week of October ( $43^{\text {rd }}$ Standard week) to first week of February ( $5^{\text {th }}$ Standard week), 2014 (Table 1). The mean population of thrips at different stages of vine in Bijapur district ranged from 0.12 to16.25 thrips/shoot/inflorescence. Less numbers of thrips were recorded after October pruning at the bud stage (3.12 thrips/bud). However, the number reached peak on first week of December (16.25 thrips/inflorescence) which coincided with initiation of flowering of grapes. Comparatively higher density of $S$. dorsalis was observed during October pruning in the present investigation, which is in close agreement with the findings of Lewis (1997) and Harish (2002) who observed peak activity of thrips during dry periods, mainly due to suitability of weather for population growth. Mean population of thrips decreased after first week of December $2013 \quad\left(48^{\text {th }}\right.$ Standard week).

\section{Relation between weather parameters and population of $S$. dorsalis (Bijapur)}

The weekly population of thrips was correlated with various weather parameters 
(maximum temperature, minimum temperature, morning and evening relative humidity, wind speed and rainfall) to assess the impact of weather parameters on the incidence of thrips.

The incidence of thrips after April pruning was significant and positively correlated (Table 3) with maximum temperature ( $\mathrm{r}=$ $0.669)$ but negatively significant correlation was observed with evening relative humidity $(\mathrm{r}=-0.582)$. The present results are agreement with Bagle (1993) and Harish (2002) who also observed the positive correlation of temperature with the population of thrips. However, non-significant correlation was found with minimum temperature $(r=0.447)$, morning relative humidity $(\mathrm{r}=-0.463)$, wind speed $(r=-0.108)$ and rainfall $(r=-0.353)$. Rainfall recorded a negative relationship with thrips incidence during April pruning. Patnaik et al., (1986) reported non-significant negative correlation of $S$. dorsalis with rainfall, which is in agreement with the present investigation.

After October pruning the incidence of thrips had positive and non-significant relationship with maximum temperature $(\mathrm{r}=0.049)$, morning relative humidity $(\mathrm{r}=0.414)$ and evening relative humidity $(\mathrm{r}=0.063)$. Whereas, it had negatively non-significant relationship with minimum temperature $(\mathrm{r}=$ $0.358)$ and wind speed $(r=-0.391)$.

Table.1 Seasonal incidence of S. dorsalis on grapes in Bijapur during 2013-14

\begin{tabular}{|c|c|c|c|c|c|}
\hline \multicolumn{3}{|c|}{ April pruning } & \multicolumn{3}{|c|}{ October pruning } \\
\hline $\begin{array}{l}\text { Stanadard } \\
\text { week }\end{array}$ & $\begin{array}{c}\text { Date of } \\
\text { observation }\end{array}$ & $\begin{array}{c}\text { Mean number of } \\
\text { thrips/ } \\
\text { budd/shoot* }\end{array}$ & $\begin{array}{c}\text { Stanadar } \\
\text { d week }\end{array}$ & $\begin{array}{c}\text { Date of } \\
\text { observation }\end{array}$ & $\begin{array}{c}\text { Mean number } \\
\text { of thrips/ bud/ } \\
\text { shoot/ } \\
\text { inflorescence/ } \\
\text { bunch* }\end{array}$ \\
\hline 18 & 28/04/2013 & 0.21 & 43 & 27/10/2013 & 3.12 \\
\hline 19 & 05/05/2013 & 9.85 & 44 & 03/11/2013 & 10.25 \\
\hline 20 & $12 / 05 / 2013$ & 13.25 & 45 & $10 / 11 / 2013$ & 15.32 \\
\hline 21 & 19/05/2013 & 14.60 & 46 & 17/11/2013 & 14.20 \\
\hline 22 & 26/05/2013 & 12.32 & 47 & 24/11/2013 & 13.28 \\
\hline 23 & 02/06/2013 & 11.32 & 48 & $01 / 12 / 2013$ & 16.25 \\
\hline 24 & 09/06/2013 & 8.20 & 49 & 08/12/2013 & 12.30 \\
\hline 25 & $16 / 06 / 2013$ & 9.68 & 50 & $15 / 12 / 2013$ & 9.25 \\
\hline 26 & 23/06/2013 & 5.32 & 51 & $22 / 12 / 2013$ & 8.52 \\
\hline 27 & 30/06/2013 & 6.24 & 52 & 29/12/2013 & 9.86 \\
\hline 28 & 07/07/2013 & 3.28 & 01 & 05/01/2014** & 4.52 \\
\hline 29 & $14 / 07 / 2013$ & 5.36 & 02 & $12 / 01 / 2014 * *$ & 6.52 \\
\hline 30 & 21/07/2013 & 3.20 & 03 & $19 / 01 / 2014 * *$ & 3.21 \\
\hline 31 & 28/07/2013 & 1.65 & 04 & $26 / 01 / 2014 * *$ & 0.96 \\
\hline 32 & 04/08/2013 & 0.92 & 05 & $02 / 02 / 2014 * *$ & 0.12 \\
\hline \multicolumn{2}{|c|}{ Mean } & 7.02 & \multicolumn{2}{|c|}{ Mean } & 8.50 \\
\hline
\end{tabular}

*Mean of Ten vines

** Observation recorded after berry maturation 
Table.2 Seasonal incidence of S. dorsalis on grapes in Bagalkot during 2013-14

\begin{tabular}{|c|c|c|c|c|c|}
\hline \multicolumn{3}{|c|}{ April pruning } & \multicolumn{2}{c|}{ October pruning } \\
\hline $\begin{array}{c}\text { Stanadard } \\
\text { week }\end{array}$ & $\begin{array}{c}\text { Date of } \\
\text { observation } \\
\text { Mean number } \\
\text { of thrips/ } \\
\text { bud/shoot* }\end{array}$ & $\begin{array}{c}\text { Stanadard } \\
\text { week }\end{array}$ & $\begin{array}{c}\text { Mean number of } \\
\text { observation } \\
\text { thrips/ bud/ shoot/ } \\
\text { inflorescence/ } \\
\text { bunch* }\end{array}$ \\
\hline 17 & $26 / 04 / 2013$ & 0.52 & 43 & $26 / 10 / 2013$ & 2.30 \\
\hline 18 & $03 / 05 / 2013$ & 3.51 & 44 & $02 / 11 / 2013$ & 6.53 \\
\hline 19 & $10 / 05 / 2013$ & 8.53 & 45 & $09 / 11 / 2013$ & 9.35 \\
\hline 20 & $17 / 05 / 2013$ & 10.50 & 46 & $16 / 11 / 2013$ & 13.12 \\
\hline 21 & $24 / 05 / 2013$ & 8.60 & 47 & $23 / 11 / 2013$ & 13.28 \\
\hline 22 & $31 / 05 / 2013$ & 6.51 & 48 & $30 / 11 / 2013$ & 14.24 \\
\hline 23 & $07 / 06 / 2013$ & 6.23 & 49 & $07 / 12 / 2013$ & 5.03 \\
\hline 24 & $14 / 06 / 2013$ & 6.03 & 50 & $14 / 12 / 2013$ & 3.50 \\
\hline 25 & $21 / 06 / 2013$ & 8.02 & 51 & $21 / 12 / 2013$ & 4.32 \\
\hline 26 & $28 / 06 / 2013$ & 2.30 & 52 & $28 / 12 / 2013$ & 5.60 \\
\hline 27 & $05 / 07 / 2013$ & 6.02 & 01 & $04 / 01 / 2014^{* *}$ & 3.50 \\
\hline 28 & $12 / 07 / 2013$ & 4.60 & 02 & $11 / 01 / 2014^{* *}$ & 4.02 \\
\hline 29 & $19 / 07 / 2013$ & 1.25 & 03 & $18 / 01 / 2014^{* *}$ & 1.50 \\
\hline 30 & $26 / 07 / 2013$ & 1.09 & 04 & $25 / 01 / 2014^{* *}$ & 0.52 \\
\hline 31 & $02 / 08 / 2013$ & 0.20 & 05 & $01 / 02 / 2014^{* *}$ & 0.12 \\
\hline & 4.92 & & & 5.79 \\
\hline
\end{tabular}

*Mean of Ten vines

**Observation recorded after berry maturation

Table.3 Correlation between incidence of thrips, $S$. dorsalis with weather parameters during 2013-14 bijapur

\begin{tabular}{|c|c|c|c|c|c|c|}
\hline \multirow{2}{*}{$\begin{array}{c}\text { Time of } \\
\text { pruning }\end{array}$} & $\begin{array}{c}\text { Max temp } \\
\left(\mathrm{X}_{1}\right)\left({ }^{0} \mathrm{c}\right)\end{array}$ & $\begin{array}{c}\text { Min temp } \\
\left(\mathrm{X}_{2}\right)\left({ }^{0} \mathrm{c}\right)\end{array}$ & $\begin{array}{c}\text { R.H.M } \\
\left(\mathrm{X}_{3}\right) \\
\%\end{array}$ & $\begin{array}{c}\text { R.H.E }\left(\mathrm{X}_{4}\right) \\
\%\end{array}$ & $\begin{array}{c}\text { WIND } \\
\text { SPEED }\left(\mathrm{X}_{5}\right) \\
(\mathrm{km} / \mathrm{hr})\end{array}$ & $\begin{array}{c}\text { Rainfall }\left(\mathrm{X}_{6}\right) \\
(\mathrm{mm})\end{array}$ \\
\hline $\begin{array}{c}\text { April } \\
\text { pruning }\end{array}$ & $0.66^{* *}$ & 0.44 & -0.46 & $-0.58^{*}$ & -0.10 & -0.35 \\
\hline $\begin{array}{c}\text { October } \\
\text { pruning }\end{array}$ & 0.40 & -0.35 & 0.41 & 0.06 & -0.39 & - \\
\hline
\end{tabular}

Significant at $\mathrm{P}=0.01 \%$

* Significant at $\mathrm{P}=0.05 \%$

Max temp = Maximum temperature

Min temp $=$ Minimum temperature

R.H.M= Morning relative Humidity

R.H.E $=$ Evening Relative Humidity 
Table.4 Multiple regression between incidence of S. dorsalis and weather parameters during 2013-14 (Bijapur)

\begin{tabular}{|c|c|c|c|c|c|c|c|c|}
\hline $\begin{array}{l}\text { Time of } \\
\text { pruning }\end{array}$ & $\begin{array}{l}\text { Intercept } \\
\text { (A) }\end{array}$ & $\begin{array}{c}\text { Max } \\
\text { Temp } \\
\left(\mathbf{X}_{1}\right) \\
\left({ }^{0} \mathbf{C}\right)\end{array}$ & $\begin{array}{c}\text { Min } \\
\text { Temp } \\
\left(\mathbf{X}_{2}\right) \\
\left({ }^{\mathbf{O}} \mathbf{C}\right)\end{array}$ & $\begin{array}{c}\text { R.H. M } \\
\left(\mathbf{X}_{\mathbf{3}}\right) \\
(\%)\end{array}$ & $\begin{array}{c}\text { R. } \\
\text { H.E } \\
\left(\mathbf{X}_{4}\right) \\
(\%)\end{array}$ & $\begin{array}{c}\text { Wind } \\
\text { speed }\left(X_{5}\right) \\
(\mathbf{k m} / \mathbf{h r})\end{array}$ & $\begin{array}{c}\text { Rain } \\
\text { fall } \\
\text { (X6) } \\
(\mathbf{m m})\end{array}$ & $\mathbf{R}^{2}$ \\
\hline $\begin{array}{c}\text { April } \\
\text { pruning }\end{array}$ & -6.708 & 2.589 & -4.076 & 0.037 & 0.235 & 0.537 & -0.062 & 0.890 \\
\hline $\begin{array}{l}\text { October } \\
\text { pruning }\end{array}$ & -83.330 & 3.564 & -1.064 & 0.041 & 0.251 & -2.674 & 0.000 & 0.658 \\
\hline
\end{tabular}

Max Temp - Maximum temperature

Min Temp - Minimum temperature

R.H. M - Morning relative humidity

R. H.E - Evening relative humidity

After regressing the incidence of thrips data with all-weather parameters after April pruning, the following multiple regression equation was obtained (Table 3 ).

$\mathrm{Y}=-6.708+2.589\left(\mathrm{X}_{1}\right)-4.076\left(\mathrm{X}_{2}\right)+0.037$ $\left(\mathrm{X}_{3}\right)+0.235\left(\mathrm{X}_{4}\right)+0.537\left(\mathrm{X}_{5}\right)-0.062\left(\mathrm{X}_{6}\right)$

Where,

$\mathrm{Y}=$ number of thrips

$\mathrm{X}_{1}=$ Maximum temperature $\left({ }^{\mathrm{O}} \mathrm{C}\right)$

$\mathrm{X}_{2}=$ Minimum temperature $\left({ }^{\circ} \mathrm{C}\right)$

$\mathrm{X}_{3}=$ Morning relative humidity $(\%)$

$\mathrm{X}_{4}=$ Evening relative humidity $(\%)$

$\mathrm{X}_{5}=$ Wind speed $(\mathrm{km} / \mathrm{hr})$

$\mathrm{X}_{6}=$ Rain fall $(\mathrm{mm})$

The multiple regression equation indicated that, for every unit increase in maximum temperature, morning relative humidity, evening relative humidity and wind speed would result in increased number of thrips by $2.589, \quad 0.037, \quad 0.235$ and 0.537 units respectively. Whereas, every unit increase in minimum temperature and rainfall, would decrease the number of thrips by 4.076 and 0.062 units respectively. The weather parameters influenced the incidence of thrips to the extent of 89.05 per cent $\left(R^{2}=0.8905\right)$.
After regressing the incidence of thrips data with all-weather parameters after October pruning the following multiple regression equation was obtained (Table 4).

$\mathrm{Y}=-83.33+3.564\left(\mathrm{X}_{1}\right)-1.064\left(\mathrm{X}_{2}\right)+0.041$

$\left(\mathrm{X}_{3}\right)+0.251\left(\mathrm{X}_{4}\right)-2.674\left(\mathrm{X}_{5}\right)-0.00\left(\mathrm{X}_{6}\right)$

The multiple regression equation indicated that, for every unit increase in maximum temperature, morning relative humidity and evening relative humidity would increase the number of thrips by 3.564, 0.041 and 0.251 units, respectively. Whereas, every unit increase in minimum temperature and wind speed would decrease the incidence of thrips by 1.064 and 2.674 units, respectively.

The weather parameters during October pruning influenced the incidence of thrips to the extent of 65.80 per cent $\left(R^{2}=0.6580\right)$.

\section{References}

Anonymous, 2012, Package of Practice for fruit crops, UHS, Bagalkot.

Bagle, B. G., 1993, Seasonal incidence and control of thrips Scirtothrips dorsalis Hood in pomegranate. Indian J. Ent., 55 (2): $148-153$. 
Dry, P. R., Hand, P.G., and Ristic, R., 2004, what is Vine Balance? Proceedings of $12^{\text {th }}$ Australian Wine Industry Technical Conference, Melbourne, Victoria, Australia, pp. 68-74.

Harish, B., 2002, Thrips complex studies in Grapes (cv. Bangalore Blue). M. Sc. (Agri.) Thesis, Univ. Agric. Sci., Bangalore (India).

Kirk, W. D. J., 1985, Aggregation and mating of thrips in flowers of Calystega sepium. Ecol. Entomol., 10: 433-440.

Lewis, T., 1997, Thrips as crop pests. CAB International, New York, pp. 7-45.
Patnaik, N. C., Behera, P. K. and Dash, A. N., 1986, some bio-ecological observations on the chilli thrips, Scirtothrips dorsalis Hood in Orissa. Orissa J. Hort., 14: 2528.

Reddy, D. B., 1957, Scab thrips of grapevine berries, Proc of the $44^{\text {th }}$ Indian Sci. Cong, 393.

Verma, S. C., Thakur, M. and Kanwar, H. S., 2012, Efficacy of insecticides against onion thrips, Thrips tabaci Lindeman on garlic under mid-hill conditions of Himachal Pradesh. J. Ins. Sci., 25 (1): 76-78.

\section{How to cite this article:}

Nagaraj R. Patil, A.M. Nadaf, Gangadhar B. Narabenchi, D.R. Patil and Sagar, B.S. 2017. Seasonal Incidence of Thrips, Scirtothrips dorsalis Hood on Grapes, Vitis vinifera L. (cv. Thompson Seedless) in Bijapur. Int.J.Curr.Microbiol.App.Sci. 6(9): 3295-3300. doi: https://doi.org/10.20546/ijcmas.2017.609.406 